\title{
PEWARISAN MARKA CyCa-DAB1*05 DAN KERAGAMAN GENETIK IKAN MAS (Cyprinus carpio) STRAIN RAJADANU TAHAN INFEKSI KOI HERPESVIRUS DAN TUMBUH CEPAT
}

\author{
Khairul Syahputra\#, Yogi Himawan, Didik Ariyanto, dan Flandrianto Sih Palimirmo \\ Balai Penelitian Pemuliaan Ikan
}

\begin{abstract}
ABSTRAK
Balai Penelitian Pemuliaan Ikan (BPPI) telah membentuk ikan mas Rajadanu tahan infeksi koi herpesvirus (KHV) dan tumbuh cepat melalui program seleksi. Ikan mas Rajadanu dihasilkan dari kegiatan seleksi bersamaan pada karakter ketahanan terhadap KHV dan pertumbuhan. Seleksi karakter ketahanan terhadap KHV dilakukan dengan menggunakan marka Cyca-DAB1*05 dan seleksi karakter pertumbuhan cepat dilakukan dengan metode seleksi individu. Penelitian ini bertujuan untuk mengevaluasi pewarisan marka Cyca-DABI*05 dan keragaman genotipe ikan mas varietas Rajadanu tahan infeksi KHV dan tumbuh cepat generasi ketiga $\left(\mathrm{F}_{3}\right)$. Sebanyak 44 individu ikan mas Rajadanu $\mathrm{F}_{3}$ digunakan pada penelitian ini. Evaluasi marka CycaDAB1*05 dilakukan dengan metode PCR menggunakan primer spesifik marka Cyca-DAB1*05. Analisis keragaman genotipe dilakukan menggunakan tiga lokus mikrosatelit (M FW6, M FW7, dan M FW9). Data alel mikrosatelit dianalisis menggunakan program Fstat dan Arlequin. Hasil penelitian menunjukkan bahwa semua individu pada populasi ikan mas Rajadanu $\mathrm{F}_{3}$ membawa marka Cyca-DAB1*05. Ikan mas Rajadanu $\mathrm{F}_{3}$ memiliki keragaman genotipe yang relatif rendah. Nilai rata-rata heterozigositas teramati $(0,31)$ lebih kecil daripada rata-rata heterozigositas harapan $(0,46)$. Nilai positif pada indeks fiksasi $(0,32)$ menunjukkan status inbreeding pada populasi tersebut. Hasil penelitian ini dapat menjadi acuan, baik dalam kegiatan manajemen induk maupun dalam program seleksi selanjutnya dengan tujuan untuk mempertahankan keragaman genetik dan meminimasi tekanan inbreeding ikan mas Rajadanu tahan infeksi KHV dan tumbuh cepat.
\end{abstract}

KATA KUNCl: ikan mas; tahan KHV; tumbuh cepat; Cyca-DAB1*05; mikrosatelit; keragaman genetik

ABSTRACT: Inheritance of Cyca-DAB1*05 marker and genetic variation of Rajadanu strain of common carp resistant to koi herpesvirus infection and fast growth. By: Khairul Syahputra, Yogi Himawan, Didik Ariyanto, and Flandrianto Sih Palimirmo

Research Institute for Fish Breeding (RIFB) has created Rajadanu common carp resistant to koi herpesvirus (KHV) infection and fast growth through selection program. Rajadanu common carp has been produced by independent culling selection on resistant to KHV and fast growth characters. Selection on resistant to KHV and fast growth character was conducted using Cyca-DAB1*05 marker and mass-selection method respectively. The aim of this study was to evaluate the inheritance of Cyca-DAB1*05 as a marker and the genotype variation of Rajadanu common carp resistant to KHV infection and fast growth. A total of 44 fish were used for this study. Evaluation of Cyca-DAB1*05 marker was conducted by PCR method using specific primer to Cyca-DAB1*05 marker. Analysis of genotype variation was conducted using three microsatellite loci (M FW6, M FW 7, and M FW9). Microsatellite allele data was analyzed using Fstat and Arlequin software. The result showed that all of $\mathrm{F}_{3}$ Rajadanu common carp were positive carrying CycaDAB1*05 marker. Genetic variation of this population was relatively low. The average observed heterozygosity $(\mathrm{Ho}=0.31)$ was lower than the average expected heterozygosity $(\mathrm{He}=0.46)$. Positive value of fixation index $(0.32)$ showed inbreeding status in this population. The result of this study can be use as reference for broodstock management and next selection program to maintain the genetic diversity and to minimize inbreeding depression level of Rajadanu common carp resistant to KHV infection and fast growth.

KEYWORDS: Common carp; resitant to KHV; fast growth; Cyca-DAB1*05; microsatellite; genetic variation

\footnotetext{
\# Korespondensi: Balai Penelitian Pemuliaan Ikan.

Jl. Raya 2 Pantura Sukamandi, Patokbeusi, Subang 41263,

Jawa Barat, Indonesia. Tel.: + (0260) 520500

E-mail: khairul_syahputra@yahoo.com
} 


\section{PENDAHULUAN}

Salah satu kendala utama dalam usaha budidaya ikan mas di Indonesia saat ini adalah timbulnya wabah penyakit koi herpesvirus (KHV). Penyakit ini telah mewabah sejak tahun 2002 (Sunarto et al., 2005). Selain penyakit, penurunan laju pertumbuhan akibat rendahnya kualitas induk dan benih juga menjadi kendala lain yang menyebabkan penurunan produksi ikan mas budidaya. Dalam rangka menanggulangi permasalahan tersebut, Balai Penelitian Pemuliaan Ikan (BPPI) mempunyai program pembentukan ikan mas tahan terhadap infeksi KHV dan tumbuh cepat. Pada tahun 2015, BPPI telah berhasil membentuk ikan mas Rajadanu tahan infeksi KHV dan tumbuh cepat generasi ketiga $\left(F_{3}\right)$ melalui program seleksi.

Ikan mas Rajadanu $\mathrm{F}_{3}$ dihasilkan dari kegiatan seleksi bersamaan pada karakter ketahanan terhadap KHV dan pertumbuhan. Seleksi karakter ketahanan terhadap KHV dilakukan dengan menggunakan marka molekuler Cyca-DAB1*05 (Alimuddin et al., 2011) dan seleksi karakter tumbuh cepat dilakukan dengan metode seleksi individu. Hasil evaluasi menunjukkan bahwa ikan mas Rajadanu $\mathrm{F}_{3}$ memiliki performa yang unggul pada karakter ketahanan terhadap infeksi KHV dan pertumbuhan (Ariyanto et al., 2015).

Sebagai bagian dari kelanjutan program pemuliaan yang telah dilakukan, karakterisasi genetik perlu dilakukan dalam rangka memonitor status keragaman genetik populasi yang telah dihasilkan. Seperti diketahui, kegiatan seleksi tidak hanya dapat memperbaiki karakter yang diinginkan, namun juga dapat memiliki efek buruk berupa penurunan keragaman genetik populasi. Norris et al. (1999) menyatakan bahwa program seleksi dapat menyebabkan penurunan keragaman genetik bila populasi atau famili yang digunakan memiliki kekerabatan yang dekat dan intensitas seleksi yang tinggi. Penurunan keragaman genetik akibat program seleksi terjadi pada populasi budidaya ikan mas di Vietnam (Thai et al., 2007), hasil penelitian Iain menunjukkan bahwa penurunan keragaman genetik terjadi pada ikan salmon Atlantik di Irlandia (Norris et al., 1999), salmon Atlantik di Norwegia (Skala et al., 2004) dan abalon di Australia (Evans et al., 2004). Selain itu, faktor lain yang dapat menurunkan keragaman genetik adalah rekaman silsilah (pedigree) yang kurang baik yang akan meningkatkan peluang penggunaan tetua yang sekerabat sehingga akan meningkatkan inbreeding depression (Norris et al., 1999; Beaumont \& Hoare, 2003; Dunham, 2004).

Penelitian ini bertujuan untuk mengevaluasi pewarisan marka Cyca-DAB ${ }^{*} 05$ dan keragaman genetik pada ikan mas Rajadanu tahan infeksi KHV dan tumbuh cepat generasi $\mathrm{F}_{3}$. Evaluasi marka MHC II sebagai marka ketahanan penyakit KHV dilakukan dengan metode PCR spesifik untuk Cyca-DAB1*05. Analisis keragaman genetik dilakukan dengan aplikasi penanda genetik DNA mikrosatelit. DNA mikrosatelit merupakan penanda genetik yang banyak digunakan untuk analisis keragaman genetik pada ikan mas (Chistiakov\& Voronova, 2009), marka genetik ini dapat digunakan untuk memonitoring perubahan variasi genetik sebagai konsekuensi dari kegiatan pemuliaan yang dilakukan (Brinez et al., 2011).

\section{BAHAN DAN METODE}

\section{Ikan Uji}

Ikan uji yang digunakan pada penelitian ini adalah populasi ikan mas Rajadanu tahan infeksi KHV dan tumbuh cepat generasi ketiga $\left(F_{3}\right)$ (Himawan et al., 2014), dengan jumlah ikan uji sebanyak 44 ekor. Populasi ikan mas Rajadanu tahan infeksi KHV dan tumbuh cepat $F_{3}$ dihasilkan dari kegiatan seleksi bersamaan (independent culling) pada karakter ketahanan terhadap KHV dan tumbuh cepat. Seleksi karakter ketahanan terhadap infeksi KHV dilakukan dengan seleksi individu yang membawa marka CycaDAB1*05 (Alimuddin et al., 2011), sedangkan seleksi karakter tumbuh cepat dilakukan dengan metode seleksi individu. Seleksi marka Cyca-DAB1*05 dilakukan pada induk-induk yang terseleksi pada karakter pertumbuhan.

Sampel sirip ekor yang berukuran sekitar $1 \mathrm{~cm}^{2}$ diambil dari setiap ikan uji dengan cara dipotong menggunakan gunting section yang telah dibersihkan dengan alkohol 70\% Sampel sirip disimpan dalam tabung mikro yang berisi $1 \mathrm{~mL}$ alkohol 70\% dan kemudian disimpan pada suhu ruang hingga dilakukan proses ekstraksi DNA.

\section{Ekstraksi DNA}

Ekstraksi DNA dari sampel sirip ekor dilakukan dengan menggunakan kit komersial GeneJET DNA Purification Kit (Thermo Scientific), dengan prosedur mengikuti protokol yang terdapat pada manual kit. Kualitas dan kuantitas DNA diukur menggunakan alat GeneQuant $\mathrm{T}^{\mathrm{TM}} 1300$. DNA hasil ekstraksi disimpan pada suhu $-20^{\circ} \mathrm{C}$ hingga dilakukan proses amplifikasi PCR.

\section{Analisis Pewarisan Marka Cyca-DAB1*05}

Analisis PCR untuk deteksi marka Cyca-DAB1*05 pada populasi ikan mas Rajadanu $\mathrm{F}_{3}$ terkait ketahanan terhadap infeksi KHV dilakukan menggunakan primer yang dapat mengamplifikasi alel Cyca-DAB $1 * 05$ (Alimuddin et al., 2011). Program PCR amplifikasi M HC II meliputi: $95^{\circ} \mathrm{C}$ selama tiga menit; $\left(95^{\circ} \mathrm{C}\right.$ selama 30 
detik; $50^{\circ} \mathrm{C}$ selama 30 detik; $72^{\circ} \mathrm{C}$ selama satu menit) sebanyak 30 siklus; dan $72^{\circ} \mathrm{C}$ selama 10 menit. Hasil amplifikasi PCR diseparasi dengan elektroforesis pada gel agarose $2 \%$ yang telah diberi pewarna GelRed ${ }^{\mathrm{TM}}$ (Biotium) dan hasil elektroforesis diamati di bawah lampu UV transiluminator dan difoto menggunakan kamera digital Canon EOS 1100D.

\section{Analisis Keragaman Genotipe}

Keragaman genotipe ikan mas Rajadanu $\mathrm{F}_{3}$ dianalisis menggunakan metode PCR dengan target tiga lokus mikrosatelit, yakni MHF6, MFW7, dan MFW9. Lokus mikrosatelit ini dipilih berdasarkan rekomendasi Yue et al. (2004) dan Thai et al. (2007) karena dapat menunjukkan polimorfisme pada ikan mas Rajadanu. Sekuens primer, kisaran produksi PCR dan suhu annealing untuk mengamplifikasi marka CycaDAB1*05 dan tiga lokus mikrosatelit disajikan pada Tabel 1. Proses PCR dilakukan dengan program: $95^{\circ} \mathrm{C}$ selama lima menit; $\left(95^{\circ} \mathrm{C}\right.$ selama 30 detik; $50^{\circ} \mathrm{C}-62^{\circ} \mathrm{C}$ selama 90 detik sesuai dengan derajat suhu penempelan (Tm) tiap primer (Tabel 1 ); $72^{\circ} \mathrm{C}$ selama 30 detik) sebanyak 32 siklus; dan $60^{\circ} \mathrm{C}$ selama 30 menit.

Polimorfisme lokus mikrosatelit di-screening dengan menggunakan alat analisis fragmen QIAxcel (Qiagen) dan menggunakan kit QIAxcel DNA High Resolution (Qiagen), dan ukuran alel-alel ditentukan berdasarkan ukuran produk PCR relatif terhadap ukuran fragmen DNA pada QX size marker 50-800 bp (Qiagen). Data pola pita dan elektroforegram dianalisis menggunakan software QIAxcel Screening gel (Qiagen) untuk menskor alel-alel yang muncul. Data skor alel kemudian digunakan untuk analisis parameter genetik yang relevan.

\section{Analisis Data}

Hasil deteksi marka Cyca-DAB1*05 pada populasi ikan mas Rajadanu tahan infeksi KHV dan tumbuh cepat $\mathrm{F}_{3}$ ditampilkan dalam bentuk gambar elektroforegram dan dianal isis secara deskriptif. Data alel mikrosatelit yang teramati diolah menggunakan program M icrosoft Excel. Parameter variabilitas genotipe meliputi jumlah alel (A), frekuensi alel, heterozigositas teramati $(\mathrm{Ho})$ dan harapan (He), Hardy-Weinberg equilibrium (HW), dan indeks fiksasi $\left(F_{\mid S}\right)$ dianalisis menggunakan software statistika genetik Fstat versi 2.9.3. (Goudet, 2001). Variasi genetik dalam dan antar individu dianalisis menggunakan AMOVA (Analysis of M olecular Variance) yang terdapat pada software Arlequin versi 3.1 (Excoffier et al., 2006).

\section{HASIL DAN BAHASAN}

\section{Analisis Marka Cyca-DAB1*05}

Berdasarkan hasil analisis marka Cyca-DAB1*05 dari 44 ekor sampel yang diperiksa menunjukkan bahwa semua individu ikan mas Rajadanu $\mathrm{F}_{3}$ tahan infeksi KHV dan tumbuh cepat membawa marka tersebut (Gambar 1). Persentase tersebut meningkat dari generasi sebelumnya, yaitu $\mathrm{F}_{1}(93,30 \%)$ dan $\mathrm{F}_{2}(86,44 \%)$ (Ariyanto et al., 2015). Persentase individu yang membawa marka Cyca-DAB1*05 pada penelitian ini lebih tinggi dibandingkan dengan ikan mas Majalaya (MANTAP) generasi $F_{2}$, yaitu 83,33 \% (Sucipto et al., 2014).

Tabel 1. Sekuen primer yang digunakan untuk mengamplifikasi marka CycaDAB1*05 dan lokus mikrosatelit polimorfik pada populasi ikan mas Rajadanu $\mathrm{F}_{3}$

Table 1. Primer sequnces used to amplification Cyca-DAB1*05 marker and polymorphic microsatellite loci in $\mathrm{F}_{3}$ Rajadanu common carp population

\begin{tabular}{|c|c|c|c|c|}
\hline $\begin{array}{l}\text { Lokus/marka } \\
\text { Locus/marker }\end{array}$ & $\begin{array}{l}\text { Motif } \\
\text { Motif }\end{array}$ & $\begin{array}{l}\text { Sekuen primer }\left(5^{\prime}-3^{\prime}\right) \\
\text { Primer sequence }\left(5^{\prime}-3^{\prime}\right)\end{array}$ & $\begin{array}{l}\text { Kisaran ukuran } \\
\text { Size range } \\
\text { (bp) }\end{array}$ & $\begin{array}{l}\mathrm{Tm} \\
\left({ }^{\circ} \mathrm{C}\right)\end{array}$ \\
\hline Cyca-DAB1*05 & & $\begin{array}{l}\text { F:CTAATGGATACTACTGG } \\
\text { R:ATCGCTGACTGTCTGTT }\end{array}$ & 300 & 50 \\
\hline MFW6 & (CA)n & $\begin{array}{c}\text { F: ACCTGATCAATCCCTGGCTC } \\
\text { R:GTTTGGGACTTTTAAATCACGTTG }\end{array}$ & 116-166 & 62 \\
\hline MFW7 & (CA)n & $\begin{array}{l}\text { F: TACTTTGCTCAGGACGGATGC } \\
\text { R:TTTATCACCTGCACATCGCCACTC }\end{array}$ & $198-222$ & 63 \\
\hline MFW9 & (CA)n & $\begin{array}{l}\text { F: GATCTGCAAGCATATCTGTCG } \\
\text { R:GTTTATCTGAACCTGCAGCTCCTC }\end{array}$ & $88-178$ & 60 \\
\hline
\end{tabular}



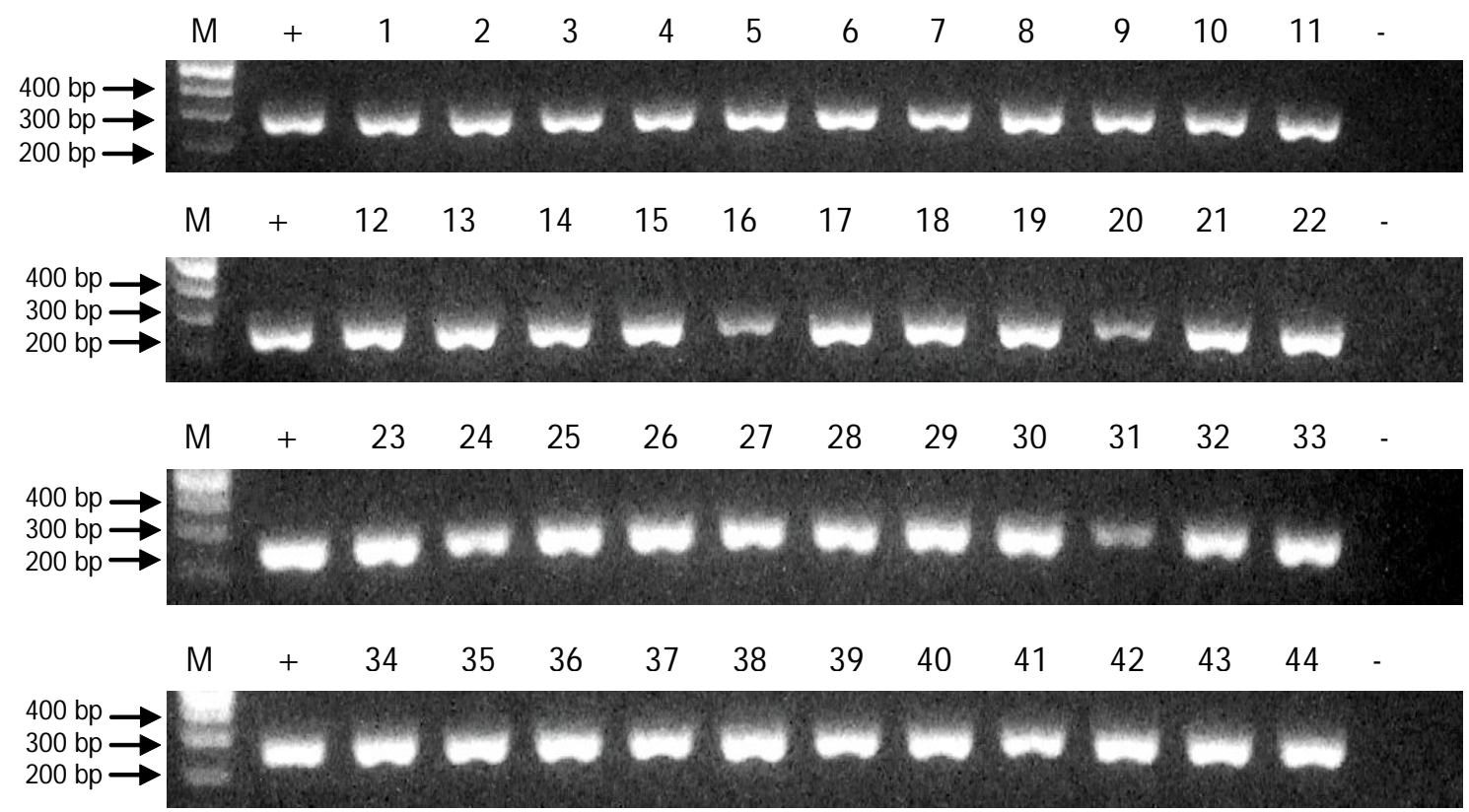

Gambar 1. Elektroferogram hasil analisis marka Cyca-DAB1*05 pada keturunan ketiga $\left(F_{3}\right)$ ikan mas Rajadanu tahan infeksi KHV dan tumbuh cepat $(M=$ marka DNA; $(+)=$ kontrol positif; $(-)=$ kontrol negatif; $1-44=$ sampel ikan mas Rajadanu $\mathrm{F}_{3}$ )

Figure 1. Electropherogram of Cyca-DAB1*05 marker analysis in $\mathrm{F}_{3}$ Rajadanu common carp resistant to KHV infection and fast growth. $M=$ DNA marker ladder; $(+)=$ positive control; $(-)=$ negative control; $1-44=F_{3}$ Rajadanu common carp samples

Peningkatan persentase ikan mas Rajadanu $\mathrm{F}_{3}$ yang membawa marka Cyca-DAB1*05 berbanding lurus dengan peningkatan ketahanannya terhadap infeksi KHV. Ariyanto et al. (2015) melaporkan bahwa ikan mas Rajadanu $\mathrm{F}_{3}$ memiliki sintasan $95,00 \%$ dan lebih baik dibandingkan dengan ikan mas Majalaya dari Unit Pembenihan Rakyat (UPR) setelah uji tantang dengan KHV pada skala laboratoium. Nilai sintasan yang tinggi pada generasi $F_{3}$ juga ditunjukkan pada generasi sebelumnya, yaitu 93,33\%pada $F_{1}$ dan 94,44\%pada $F_{2}$. Marka Cyca-DAB1*05 merupakan marka molekuler ketahanan terhadap penyakit KHV pada ikan mas (Rakus et al., 2009; Alimuddin et al., 2011), sehingga marka ini dapat digunakan dalam kegiatan seleksi untuk membentuk ikan mas Rajadanu tahan KHV. Marka Cyca-DAB1*05 juga telah digunakan pada kegiatan seleksi ikan mas Majalaya (MANTAP) tahan KHV (Sucipto et al., 2014).

\section{Variasi Genotipe Ikan Mas Rajadanu $\mathbf{F}_{\mathbf{3}}$}

Ketiga primer mikrosatelit yang digunakan pada penelitian ini dapat mengamplifikasi dan menghasilkan lokus mikrosatelit yang polimorfik pada populasi ikan mas Rajadanu $\mathrm{F}_{3}$. Total sebanyak 12 alel yang berbeda teridentifikasi dari ketiga lokus yang dianalisis dengan kisaran panjang alel 88-222 bp. Lokus MFW 6 merupakan lokus yang paling bervariasi dengan jumlah alel enam, diikuti oleh lokus MFW9 dengan empat alel, sedangkan lokus M FW 7 merupakan lokus yang paling rendah variasinya dengan jumlah alel yang teridentifikasi sebanyak dua (Tabel 2). Rata-rata jumlah alel tiap lokus adalah empat alel, rata-rata jumlah alel ini lebih sedikit dibandingkan dengan rata-rata jumlah alel yang teridentifikasi pada generasi sebelumnya, yaitu 4,3 alel pada $F_{1}$ dan 3,7 pada $F_{2}$ (Ariyanto et al., 2015). Berkurangnya jumlah alel dapat disebabkan oleh kegiatan seleksi yang dilakukan, keterbatasan jumlah induk yang digunakan dalam pembentukan populasi seleksi menyebabkan alel-al el dengan frekuensi rendah tidak diwariskan (Norris et al., 1999). Meskipun terjadi reduksi jumlah alel, akan tetapi metode seleksi yang digunakan pada pembentukan ikan mas Rajadanu $\mathrm{F}_{3}$ tahan KHV dan tumbuh cepat dapat mengendalikan penurunan jumlah alel pada tiap generasi.

Rata-rata jumlah alel yang teridentifikasi pada penelitian ini lebih sedikit dibandingkan dengan penelitian lainnya pada ikan mas. Thai et al. (2007) melaporkan bahwa sebanyak 4,33 rata-rata jumlah alel teridentifikasi pada ikan mas Sinyonya (Indonesian yellow carp) di Vietnam dari tiga lokus mikrosatelit MFW6, MFW7, dan MFW 9, sedangkan Biba et al. (2015) melaporkan bahwa dari tiga lokus yang sama teridentifikasi 25,33 alel untuk rata-rata jumlah pada populasi ikan mas di Danau Shkodra, Albania. 
Tabel 2. Variabilitas genetik dari tiga lokus mikrosatelit pada ikan mas tahan infeksi KHV dan tumbuh cepat generasi $F_{3}$

Table 2. Genetic variability of three microsatellite loci in $\mathrm{F}_{3}$ Rajadanu common carp resistant to KHV and fast growth

\begin{tabular}{|c|c|c|}
\hline $\begin{array}{l}\text { Lokus } \\
\text { Loci }\end{array}$ & $\begin{array}{l}\text { Parameter } \\
\text { Parameters }\end{array}$ & $\begin{array}{c}\text { Populasi } \mathbf{F}_{3} \\
\mathbf{F}_{3} \text { population }\end{array}$ \\
\hline \multirow{7}{*}{ MFW6 } & Kisaran panjang alel (Alelle size range) (bp) & $116-166$ \\
\hline & Jumlah sampel (Number of sample) (N) & 41 \\
\hline & Jumlah alel (A) (Number of alelle) & 6 \\
\hline & Heterozigositas teramati (Observed heterozygosity) (Ho) & 0.22 \\
\hline & Heterozigositas harapan (Expected heterozygosity) $(\mathrm{He})$ & 0.48 \\
\hline & Indeks fiksasi (Fixation index ) (Fis) & 0.54 \\
\hline & Nilai $p$ Hardy-weinberg ( $p$ value Hardy-W einberg) (HW) & 0 \\
\hline \multirow{7}{*}{ MFW7 } & Kisaran panjang alel (Alelle size range) (bp) & $198-222$ \\
\hline & Jumlah sampel (Number of sample) (N) & 44 \\
\hline & Jumlah alel (A) (Number of alelle) & 2 \\
\hline & Heterozigositas teramati (Observed heterozygosity) (Ho) & 0.41 \\
\hline & Heterozigositas harapan (Expected heterozygosity) $(\mathrm{He})$ & 0.48 \\
\hline & Indeks fiksasi (Fixation index ) (Fis) & 0.15 \\
\hline & Nilai $p$ Hardy-weinberg ( $p$ value Hardy-W einberg ) (HW) & 0.349 \\
\hline \multirow{7}{*}{ MFW9 } & Kisaran panjang alel (Alelle size range) (bp) & $88-178$ \\
\hline & Jumlah sampel (Number of sample) (N) & 43 \\
\hline & Jumlah alel (A) (Number of alelle) & 4 \\
\hline & Heterozigositas ter amati (Observed heterozygosity) ( $\mathrm{Ho})$ & 0.3 \\
\hline & Heterozigositas harapan (Expected heterozygosity) (He) & 0.41 \\
\hline & Indeks fiksasi (Fixation index ) (Fis) & 0.27 \\
\hline & Nilai $p$ Hardy-weinberg ( $p$ value Hardy-W einberg ) (HW) & 0.012 \\
\hline \multirow{4}{*}{$\begin{array}{l}\text { Rata-rata } \\
\text { Average }\end{array}$} & Jumlah alel (A) (Number of alelle) (N) & 4 \\
\hline & Heterozigositas teramati (Observed heterozygosity) (Ho) & 0.31 \\
\hline & Heterozigositas harapan (Expected heterozygosity) (He) & 0.46 \\
\hline & Indeks fiksasi (Fixation index ) (Fis) & 0.32 \\
\hline
\end{tabular}

Perbedaan jumlah alel yang teramati pada penelitian ini dibandingkan dengan penelitian lainnya dapat dipengaruhi oleh perbedaan metode dan strain ikan mas yang diuji, dan perbedaan jenis populasi yang diuji. Populasi ikan mas Sinyonya (Indonesian yellow carp) merupakan populasi ikan mas hasil program seleksi di Vietnam (Thai et al., 2007), sedangkan ikan mas di Danau Shkodra, Albania merupakan populasi ikan mas tipe liar (Biba et al., 2015).

Frekuensi alel yang teramati dari ketiga lokus menunjukkan struktur genotipe dari populasi ikan mas Rajadanu $\mathrm{F}_{3}$. Pada lokus M FW 6 teridentifikasi satu alel yang dominan dari alel lainnya dengan frekuensi paling tinggi $(0,71)$, yaitu alel 152 . Satu alel yang dominan juga teridentifikasi pada lokus MFW 9 yaitu alel 122 dengan frekuensi alel 0,73 . Selain alel dengan frekuensi yang tinggi, pada populasi ikan mas Rajadanu $\mathrm{F}_{3}$ juga ditemukan beberapa alel jarang atau alel dengan nilai frekuensi alel lebih kecil dari 5\%(Cole, 2005; Hale et al., 2012). Tiga alel jarang teramati pada lokus M FW 6 dan dua alel pada lokus MFW9. Alel 116, 128, dan 136 merupakan alel jarang yang teramati pada lokus M FW 6 , alel 138 dan 178 merupakan alel jarang pada lokus MFW9. Alel jarang tidak ditemukan pada lokus MFW7 (Gambar 2).

Nilai heterozigositas menunjukkan status keragaman genetik ikan mas Rajadanu $F_{3}$. Populasi ikan mas Rajadanu $F_{3}$ memiliki nilai rata-rata heterozigositas teramati (Ho) 0,31 dan heterozigositas harapan (He) 0,46. Defisit heterozigositas teridentifikasi pada penelitian ini, hal ini ditunjukkan dengan nilai Ho populasi ikan mas Rajadanu $\mathrm{F}_{3}$ lebih kecil dari He baik pada tiap lokus maupun dalam populasi. Dua dari tiga lokus yang diuji 


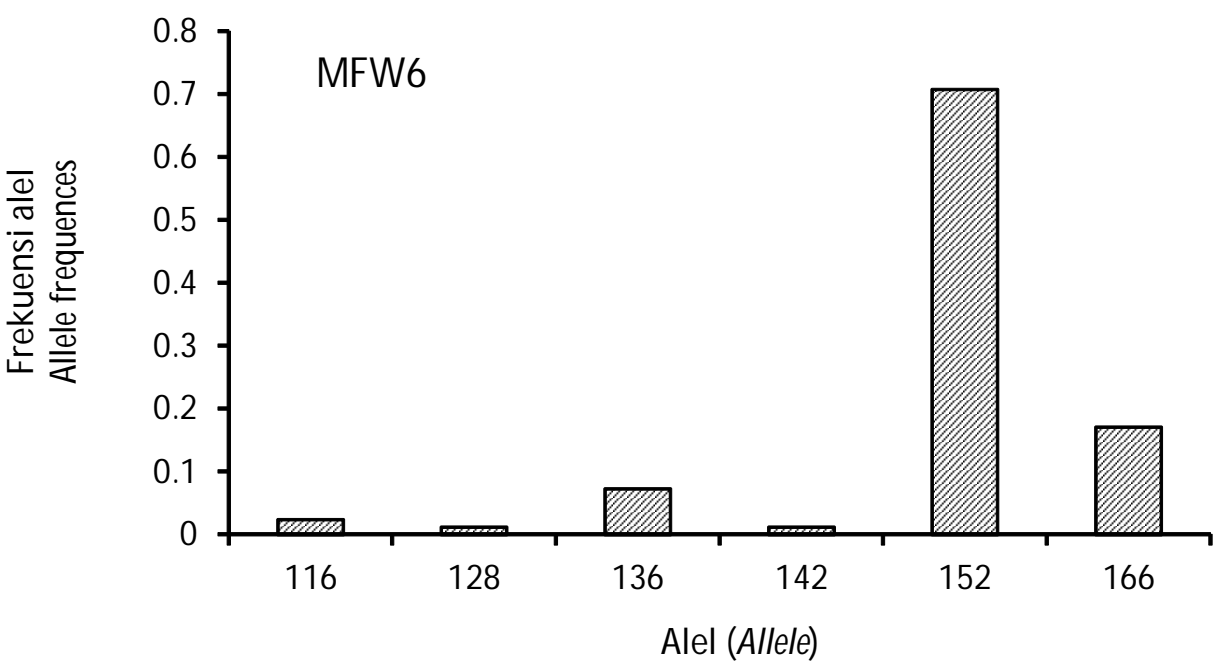

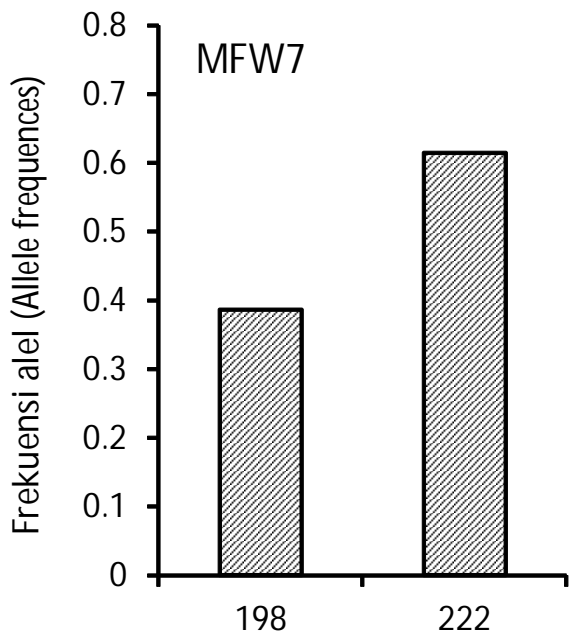

Alel (Allele)

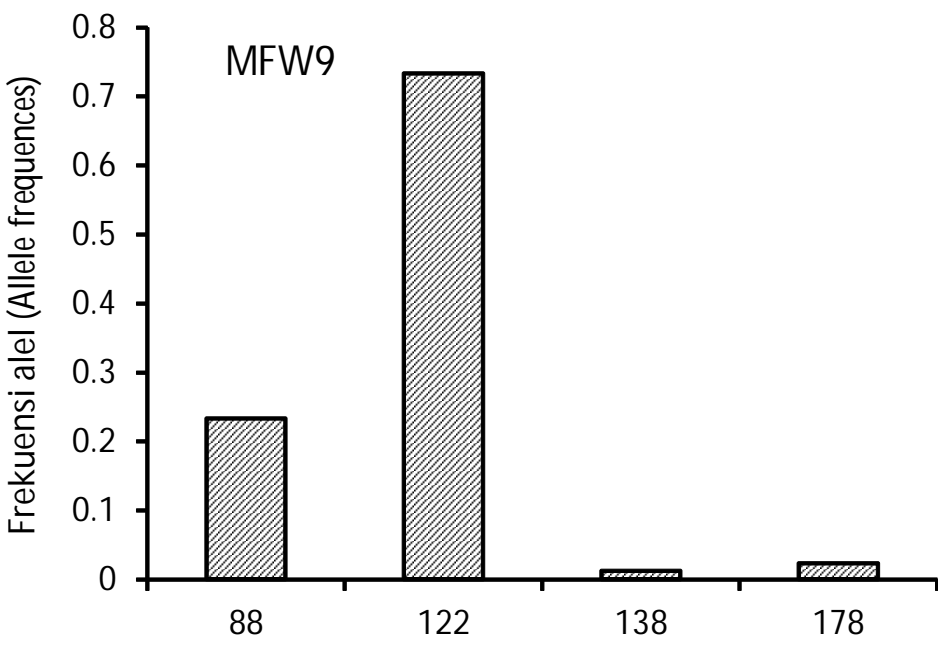

Alel (Allele)

Gambar 2. Jumlah alel dan distribusi frekuensi alel pada populasi $F_{3}$ ikan mas Rajadanu tahan infeksi KHV dan tumbuh cepat dari tiap lokus mikrosatelit MFW6, MFW7, dan MFW9

Figure 2. Number of allele and distribution of allele frequencies on each microsatellite loci M FW6, M FW 7, and M FW 9 in $\mathrm{F}_{3}$ Rajadanu common carp resistant to KHV and fast growth

menunjukkan adanya deviasi terhadap kesetimbangan Hardy-Weinberg $(P<0,05)$, yaitu lokus MFW6 dan MFW9. Hasil ini mengindikasikan bahwa keragaman genotipe ikan mas Rajadanu $\mathrm{F}_{3}$ relatif rendah. Meskipun memiliki keragaman genotipe rendah, namun sebaliknya ikan mas Rajadanu $F_{3}$ memiliki variasi fenotipe pertumbuhan yang lebih tinggi. Hal ini ditunjukkan dengan nilai koefisien variasi karakter bobot ikan mas Rajadanu $\mathrm{F}_{3}$ sebesar $60,94 \%$ (Himawan et al., 2014). Oleh karena itu, dapat dikatakan bahwa lokus mikrosatelit yang digunakan pada penelitian ini tidak berhubungan dengan variasi pertumbuhan ikan mas Rajadanu $\mathrm{F}_{3}$.
Heterozigositas penting bagi suatu populasi baik ikan budidaya maupun ikan liar karena heterozigositas akan memberikan genotipe dengan spektrum luas sebagai bentuk respons adaptif terhadap perubahan lingkungan. Umumnya, individu-individu yang heterozigot lebih superior daripada individu yang kurang heterozigot pada berbagai karakter yang bernilai ekonomis penting seperti pertumbuhan, fertilitas, dan ketahanan penyakit (Beardmore et al., 1997; Hosseinnia et al., 2014).

Nilai heterozigositas populasi ikan mas Rajadanu $\mathrm{F}_{3}$ relatif lebih rendah jika dibandingkan dengan nilai heterozigositas teramati pada sembilan jenis ikan mas 
domestikasi di Indonesia yang dilaporkan oleh Aliah \& Taniguchi (1999), yaitu berkisar antara 0,44-0,74. Namun, jika dibandingkan dengan tetuanya, ikan mas Rajadanu $F_{3}$ tidak menunjukkan adanya reduksi heterozigositas sebagai akibat kegiatan seleksi yang dilakukan. Ariyanto et al. (2014) melaporkan bahwa heterozigositas populasi ikan mas Rajadanu yang dianalisis menggunakan metode RAPD adalah 0,274. Populasi tersebut digunakan sebagai tetua (P) untuk kegiatan pembentukan ikan mas Rajadanu tahan KHV dan tumbuh cepat. Rendahnya keragaman genetik ikan mas Rajadanu $\mathrm{F}_{3}$ tidak disebabkan oleh metode seleksi yang dilakukan, akan tetapi lebih disebabkan karena penggunaan jumlah induk atau tetua yang terbatas dan memiliki keragaman genetik yang rendah. Induk tetua yang digunakan merupakan populasi survivor terhadap serangan virus KHV dan terseleksi berdasarkan marka Cyca-DAB1*05. Jumlah induk ikan mas yang digunakan sebagai tetua untuk membentuk ikan mas Rajadanu $\mathrm{F}_{3}$ berjumlah 55 ekor yang terdiri atas 30 ekor induk betina dan 25 ekor induk jantan (Ariyanto et al., 2013). Pembentukan populasi seleksi ikan mas Rajadanu tahan KHV dan tumbuh cepat mengacu pada protokol pemuliaan ikan mas, pembentukan populasi seleksi dilakukan dengan pemijahan 30 pasang dan metode persilangan backcross dilakukan untuk membentuk populasi $F_{1}, F_{2}$, dan $F_{3}$ (Ariyanto et al., 2015).

Defisit heterozigositas yang terjadi pada populasi ikan mas Rajadanu $\mathrm{F}_{3}$ berkorelasi terhadap nilai indeks fiksasi (fixation index, Fis) yang menunjukkan status breeding populasi tersebut. Pada Tabel 2 menunjukkan bahwa nilai Fis populasi adalah 0,32; lokus MFW6 memberikan nilai Fis terbesar dan diikuti oleh lokus MFW 9 dan MFW7. Nilai Fis yang positif mengindikasikan level inbreeding dari populasi ikan mas Rajadanu $\mathrm{F}_{3}$. Nilai Fis berkisar antara -1 dan +1 , nilai positif pada Fis mengindikasikan inbreeding sedangkan nilai negatif mengindikasikan outbreeding (Keller \& Waller, 2002; Vlaeva \& Lukanova, 2015).

Berdasarkan hasil analisis variasi genetik dengan AMOVA, variasi genetik dalam individu memberikan kontribusi terbesar dibandingkan variasi genetik antar individu terhadap variasi genetik ikan mas Rajadanu $\mathrm{F}_{3}$. Pada Tabel 3 menunjukkan bahwa variasi genetik dalam individu memberikan kontribusi 67,73\% sedangkan variasi genetik antar individu hanya memberikan kontribusi sebesar 32,27\%

Meskipun keragaman genetiknya relatif rendah, ikan mas Rajadanu $\mathrm{F}_{3}$ memiliki performa yang relatif lebih baik pada karakter ketahanan terhadap infeksi KHV dan pertumbuhan dibandingkan dengan kontrol dan ikan mas yang beredar di masyarakat (Ariyanto et al., 2015). Program dan metode seleksi yang digunakan pada kegiatan pembentukan ikan mas Rajadanu tahan infeksi KHV dan tumbuh cepat mampu mengendalikan tingkat keragaman genetik dan level inbreeding dari tetua hingga generasi ketiga.

\section{KESIMPULAN}

Ikan mas Rajadanu $F_{3}$ membawa marka CycaDAB 105 dengan persentase $100 \%$ Keragaman genetik ikan mas Rajadanu $\mathrm{F}_{3}$ relatif rendah, defisit heterozigositas, dan inbreeding teramati pada populasi tersebut. Ikan mas Rajadanu $\mathrm{F}_{3}$ tidak menunjukkan penurunan keragaman genetik dibandingkan dengan generasi sebelumnya. Variasi genetik dalam individu memberikan kontribusi terbesar dibandingankan variasi genetik antar individu terhadap variasi genetik ikan mas Rajadanu $\mathrm{F}_{3}$.

\section{UCAPAN TERIMA KASIH}

Penelitian ini dibiayai oleh Anggaran Pendapatan dan Belanja Negara (APBN) melalui DIPA Tahun Anggaran

Tabel 3. AM OVA (Analysis of M olecular Variance) ikan mas Rajadanu tahan infeksi KHV dan tumbuh cepat generasi $\mathrm{F}_{3}$

Table 3. AM OVA (Analysis of M olecular Variance) of $\mathrm{F}_{3}$ Rajadanu common carp resistant to KHV and fast growth

\begin{tabular}{lccc}
\hline $\begin{array}{l}\text { Sumber keragaman } \\
\text { Source of variations }\end{array}$ & $\begin{array}{c}\text { Jumlah kuadrat } \\
\text { Sum of squares }\end{array}$ & $\begin{array}{c}\text { Komponen ragam } \\
\text { Variation components }\end{array}$ & $\begin{array}{c}\text { Persentase ragam } \\
\text { Percentage of variations }\end{array}$ \\
\hline $\begin{array}{l}\text { Antar individu } \\
\text { Among individuals }\end{array}$ & 37.71 & 0.22 & 32.27 \\
$\begin{array}{l}\text { Dalam individu } \\
\text { Within individuals }\end{array}$ & 20.00 & 0.47 & 67.73 \\
\hline \multicolumn{1}{c}{ Total (Total) } & $\mathbf{5 7 . 7 1}$ & $\mathbf{0 . 6 9}$ & \\
\hline
\end{tabular}


2014 di Balai Penelitian Pemuliaan Ikan, Sukamandi. Terima kasih disampaikan kepada semua teknisi yang telah membantu dalam kegiatan penelitian ini. Terima kasih juga disampaikan kepada dewan redaksi untuk semua saran, masukan, dan perbaikan terhadap makalah ini.

\section{DAFTAR ACUAN}

Aliah, R.S., \& Taniguchi, N. (1999). Comparison of genetic variability in nine domesticated stocks of Indonesian common carp by using microsatellite DNA markers. Fish Genetics and Breeding Science, 28, 121-130.

Alimuddin, Mubinun, Santika, A., Charman, O., Faizal, I., \& Sumantadinata. K. (2011). Identification of Majalaya common carp strains resistant to KHV infection using Cyca-DAB1 $* 05$ allele as the marker. Indonesian Aquaculture Journal, 6(2), 157-163.

Ariyanto, D., Hayuningtyas, E.P., \& Syahputra, K. (2013). Peningkatan mutu genetik karakter pertumbuhan ikan mas rajadanu hasil seleksi generasi ke-0 (G-0). Makalah disampaikan pada Seminar Hasil Penelitian. Balai Penelitian Pemuliaan Ikan, Sukamandi.

Ariyanto, D., Hayuningtyas, E.P., \& Syahputra, K. (2014). Koleksi, karakterisasi, dan seleksi plasma nutfah ikan mas (Cyprinus carpio) tahan penyakit koi herpes virus. J. Ris. Akuakultur, 9(2), 215-228.

Ariyanto, D., Syahputra K., \& Himawan, Y. (2015). Naskah akademik pelepasan varietas unggul ikan mas Rajadanu tahan penyakit koi herpesvirus (KHV). Balai Penelitian Pemuliaan Ikan. Sukamandi, $90 \mathrm{hlm}$.

Biba, A., Hoda, A., Vardhami, E., \& Bozg, V. 2015. Genetic diversity of common carp from Shkodra Lake based on microsatellite markers. Livestock Research for Rural Development, 27(4), 1-4.

Beardmore, J.A., Mair, G.C., \& Lewis, R.I. (1997). Biodiversity in aquatic systems in relation to aquaculture. Aquac. Res., 28, 829-839.

Beaumont, R.A., \& Hoare, K. (2003). Biotechnology and genetics in fisheries and aquaculture. Blackwell Publishing, Oxford.

Brinez, B.R., Caraballo, X.I., \& Salazar, M.V. (2011). Genetic diversity of six populations of red hybrid tilapia, using microsatellites genetic markers. Rev. M VZ Cordoba, 16(2), 2491-2498.

Chistiakov, D.A., \& Voronova, N.V. (2009). Genetic evolution and diversity of common carp Cyprinus carpio L. Cent. Eur. J. Biol., 4(3), 304-312.

Cole, C.T. (2005). Allelic and population variation of microsatellite loci in aspen (Populus tremuloides). New Phytologist, 167, 155-164.
Dunham, A.R. (2004). Aquaculture and fisheries biotechnology genetic approaches. CABI Publishing, Oxfordshire, $115 \mathrm{pp}$.

Evans, B., Bartlett, J., Sweijd, N., Cook, P., \& Elliot, N.G. (2004). Loss of genetic variation at microsatellite loci in hatchery produced abalone in Australia (Haliotis rubra) and South Africa (Haliotis midae). Aquaculture, 233, 109-127.

Excoffier, L., Laval, G., \& Schneider, S. (2006). Arlequin ver. 3.0: An integrated software package for population genetics data analysis. Evolutionary Bioinformatics Online, 1, 47-50.

Goudet, J. (2001). FSTAT, a program to estimate and test gene diversities and fixation indices (version 2.9.3). Institute of Ecology, University of Lausanne, Switzerland. http://www.unil.ch/izea/ software/fstat.html.

Hale, M.L., Burg, T.M., \& Steeves, T.E. (2012). Sampling for microsatellite based population genetic studies: 25 to 30 individuals per population is enough to accurately estimate allele frequencies. PLoS One, 7(9), e45170.

Himawan, Y., Syahputra, K., \& Ariyanto, D. (2014). Evaluasi dan uji performa benih ikan mas Rajadanu tahan KHV dan tumbuh cepat generasi ketiga. Laporan Teknis Hasil Penelitian BPPI tahun 2014. Sukamandi, $26 \mathrm{hlm}$.

Hosseinnia, Z., Shabany, A., \& Kolangi-Miandare, H. (2014). Comparison of genetic variation of wild and farmed Bream (Abramis brama orientalis; berg, 1995) using microsatellite markers. Molecular Biology Research Communications, 3(3), 187-195.

Keller, L.F., \& Waller, D.M. (2002). Inbreeding effects in wild populations. Trends in Ecology and Evolution, 17, 230-241.

Norris, A.T., Bradley, D.G., \& Cunningham, E.P. (1999). Microsatellite genetic variation between and within farmed and wild Atlantic salmon (Salmo salar) populations. Aquaculture, 180, 247-264.

Rakus, K.L., Wiegertjes, G.F., Adamek, M., Siwicki, A.K., Lepa, A., \& Irnazarow, I. (2009). Resistance of common carp (Cyprinus carpio L.) to Cyprinid herpesvirus-3 is influenced by major histocompatibility (MH) class II B gene polymorphism. Fish $\&$ Shellfish Immunology, 26, 737-743.

Skala, O., Hoyheim, B., Glover, K., \& Dahle, G. (2004). Microsatellite analysis in domesticated and wild Atlantic salmon (Salmo salar L.): allelic diversity and identification of individuals. Aquaculture, 240, 131-143.

Sucipto, A., Faridah, N., Mundayana, Y., Haniyanti, D., Santika, A., Mawardi, M., Handayani, D.I., Prayoga, T., Purwanto, J., Juanda, T., \& Dimyati, A. (2014). 
Naskah akademik ikan mas (Cyprinus carpio) Majalaya tahan penyakit. Balai Besar Perikanan Budidaya Air Tawar. Sukabumi, $38 \mathrm{hlm}$.

Sunarto, A., Taukhid, Rukyani, A., Koesharyani, I., Supriyadi, H., Gardenia, L., Huminto, H., Agungpriyono, D.R., Pasaribu, F.H., Herdikiawan, D., Rukmono, D., \& Prayitno, B. (2005). Field investigations on a serious disease outbreak among koi and common carp (Cyprinus carpio) in Indonesia. In Walker, P., Lester, R., \& Bondad-Reantaso, M.G. (Eds.). Diseases in Asian Aquaculture V, p. 125135. Fish Health Section, Asian Fisheries Society, Manila.
Thai, B.T., Burridge C.P., \& Austin, C.M. (2007). Genetic diversity of common carp (Cyprinus carpio L.) in Vietnam using four microsatellite loci. Aquaculture, 269, 174-186.

Vlaeva, R., \& Lukanova, N. (2015). DNA microsatellite analysis of the thoroughbred horse population in Bulgaria. Genetic relationships between the studied sirelines. Trakia Journal of Sciences, 13(1), 8387.

Yue, G.H., Ho, M.Y., Orban, L., \& Komen, J. (2004). Microsatellites within genes and ESTs of common carp and their applicability in silver crucian carp. Aquaculture, 234, 85-98. 